\title{
DNA extractions from deep subseafloor sediments: Novel cryogenic-mill- based procedure and comparison to existing protocols
}

\author{
Karine Alain ${ }^{a,{ }^{*}}$, Nolwenn Callac ${ }^{c}$, Maria-Cristina Ciobanu ${ }^{b}$, Yann Reynaud ${ }^{b}$, \\ Frédérique Duthoit ${ }^{\mathrm{b}}$, Mohamed Jebbar ${ }^{\mathrm{a}}$
}

a CNRS, Institut Universitaire Européen de la Mer (IUEM) - UMR 6197, Laboratoire de Microbiologie des Environnements Extrêmes (LMEE), Place Nicolas Copernic, F-29280 Plouzané, France

b Université de Bretagne Occidentale (UBO, UEB), IUEM - UMR 6197, Laboratoire de Microbiologie des Environnements Extrêmes (LMEE), Place Nicolas Copernic, F-29280 Plouzané, France

c Ifremer, UMR6197, Laboratoire de Microbiologie des Environnements Extrêmes (LMEE), Technopôle Pointe du diable, F-29280 Plouzané, France

\author{
*: Corresponding author: Karine Alain, Tel: +33-(0)2-98-49-88-53 ; Fax: +33-(0)2-98-49-87-05 ; \\ email address : Karine.Alain@univ-brest.fr
}

\begin{abstract}
:
Extracting DNA from deep subsurface sediments is challenging given the complexity of sediments types, low biomasses, resting structures (spores, cysts) frequently encountered in deep sediments, and the potential presence of enzymatic inhibitors. Promising results for cell lysis efficiency were recently obtained by use of a cryogenic mill (Lipp et al., 2008). These findings encouraged us to devise a DNA extraction protocol using this tool. Thirteen procedures involving a combination of grinding in liquid nitrogen (for various durations and beating rates) with different chemical solutions (phenol, chloroform, SDS, sarkosyl, proteinase, GTC), or with use of DNA recovery kits (MagExtractor $\left.{ }^{\circledR}\right)$ were compared. Effective DNA extraction was evaluated in terms of cell lysis efficiency, DNA extraction efficiency, DNA yield and determination of prokaryotic diversity. Results were compared to those obtained by standard protocols: the FastDNA®SPIN kit for soil and the Zhou protocol. For most sediment types grinding in a cryogenic mill at a low beating rate in combination with direct phenol-chloroform extraction resulted in much higher DNA yields than those obtained using classical procedures. In general (except for clay-rich sediments), this procedure provided high-quality crude extracts for direct downstream nested-PCR, from cell numbers as low as $1.1 \times 10^{6} \mathrm{cells} / \mathrm{cm}^{3}$. This procedure is simple, rapid, low-cost, and could be used with minor modifications for large-scale DNA extractions for a variety of experimental goals.
\end{abstract}

\section{Highlights}

- Cryogenic-mill was tested as a tool for the first step of DNA extraction from subsurface sediments. - High cell lysis efficiencies using cryogenic-mill were obtained on different sediment types. Thirteen procedures were compared to recover DNA: chemical extractions or kits. Grinding at low beating rate followed by phenol-chloroform extraction results in high DNA yields. - It provides highquality crude extracts for direct downstream nested-PCR, from low cell numbers.

Keywords : Sediment ; DNA extraction ; Deep subsurface biosphere 


\section{Introduction}

The deep subsurface environment is one of the least explored biotopes on Earth. Microbiological investigations give evidence for a remarkably abundant and diverse microbial population to depths of 1626 meters below the sea floor (mbsf) and in sediments dating 111 million years (My) old (Fry et al., 2008; Roussel et al., 2008). These prokaryotes are to some extent alive and metabolically active (Schippers et al., 2005; Lipp et al., 2008). To date there are many questions regarding the subseafloor microbial communities, their composition, their abundance and their interactions with the basaltic lithosphere and oceanic hydrosphere. To acquire a representative description of the microbial diversity, molecular methods need to be used (Fry et al., 2008) and reliable qualitative and quantitative DNA extracts are necessary.

Obtaining representative DNA extracts from entire subsurface communities is critical, but challenging due to the low concentrations of nucleic acids that can be extracted, the adsorption of cells to sediment/rock particles, and the frequent co-extraction of enzymatic inhibitors (heavy metals, colloids, fulvic and humic acids, etc.). Therefore, DNA extraction procedures alone cannot be used to estimate microbial diversity, but require combination and optimization with other methods (Madsen, 1996; Martin-Laurent et al., 2001; Luna et al., 2006). Previous efforts to extract DNA from sediments were based on the evaluation of two main procedures: first, cells separated from the sediment matrix and lysed (cell extraction) and second, cells lysed within the sediment (direct cell lysis) (Steffan et al., 1988; Leff et al., 1995; Luna et al., 2006). Direct cell lysis protocols provide higher DNA yields, ribotype richness and diversity, as compared to cell extraction procedures (Leff et al., 1995; Courtois et al., 2001; Luna et al., 2006). Several variations of direct cell lysis protocols are described in the literature (Zhou et al., 1996; Miller et al., 1999; Webster et al., 2003; Luna et al., 2006). They are based on mechanical disruption (freeze-thawing, bead-mill homogenization and/or sonication), chemical lysis (detergents, $\mathrm{NaCl}$ and/or chaotropic agents) and enzymatic lysis (lysozyme, proteinase $\mathrm{K}$, achromopeptidase and/or proteinase $\mathrm{E}$ ). Regarding deep marine sediment samples, the most commonly used protocols are the Zhou method (Zhou et al., 1996) and the bead-beating. The former technique combines freeze-thawing in a high-salt extraction buffer followed by chemical lysis at $65^{\circ} \mathrm{C}$, in the presence of sodium dodecyl sulfate (SDS), hexadecyltrimethylammonium bromide (CTAB) and proteinase $\mathrm{K}$. The bead-beating method is based on a commercially available kit 'FastDNA ${ }^{\circledR}$ SPIN for Soil' (Qbiogene) that has been modified according to Webster et al. (2003). At the present time, detailed DNA extraction procedures using a cryogenic mill are not yet described in the literature even though there are some preliminary reports suggesting that grinding in liquid nitrogen may increase DNA yields extracted from deep sediment samples (Lipp et al., 2008).

The first objective of this study was to establish a protocol that allows for efficient extraction of DNA from subsurface sediments and rocks using a cryogenic laboratory mill. The cryogenic laboratory mill is an apparatus that allows for chilling samples in liquid nitrogen and pulverizing them with a magnetically driven impactor. Given the variety of sediment types (various compositions and grain sizes) and the multitude of factors impacting DNA extraction, we aimed to develop a comprehensive method that could be applied to a wide variety of sediments. Our procedure took into account clay, silt and sandy sediment types from the Mediterranean Sea, then these methods were analyzed on 'standard' sediment (silt) from Tasman Sea and finally the results were compared and validated with samples from various depths and locations.

The second aim of this work was to compare the relative effectiveness for the Freezer/Millbased protocol to the established protocols (the Zhou and the bead-beating methods). To do this, we took into account several criteria including DNA yield, purity, and determination of prokaryotic diversity. Finally, our approach established a fundamental protocol for DNA 
extraction that should be suitable for many marine subsurface sediments and experimental goals.

\section{Material and methods}

\subsection{Samples}

Subseafloor marine sediments and rocks were collected from various locations (Table 1). They were dissimilar in their physical characteristics, their chemical properties, and their age (Table 1):

(1) Mediterranean Sea: sediments were collected from the Var sedimentary Ridge and the Gulf of Lions, during the RHOSOS and ESSCAR9 cruises (R/V Le Suroit) in September-October 2008 by a Kullenberg (Calypso) corer. Sediments had high organic matter content and different grain sizes. In the laboratory, the core liners were aseptically opened and subsamples were collected from the inner part of the cores using end-cut sterile $2 \mathrm{ml}$ syringes. $100-150 \mathrm{~cm}^{3}$ samples were directly frozen at $-80^{\circ} \mathrm{C}$ for molecular analyses (DNA extractions); $1 \mathrm{~cm}^{3}$ samples for cells counts were placed in $15 \mathrm{ml}$ vials containing $9 \mathrm{ml}$ of $4 \%$ formalin $/ 30 \mathrm{~g} . \mathrm{I}^{-1} \mathrm{NaCl}$ solution and stored at $4^{\circ} \mathrm{C}$.

(2) Tasman Sea: sediment samples were collected by Geosciences Australia from the Australian maritime jurisdiction during the AUSFAIR survey (R/V Marion Dufresne), in February 2006 by a Calypso piston corer. Cores were immediately sliced aseptically onboard and subsampled using $5 \mathrm{ml}$ syringes (luer end removed) from the inner part of the core. Subsamples were stored at $-80^{\circ} \mathrm{C}$ for molecular analysis and at $4{ }^{\circ} \mathrm{C}$ for prokaryotic enumeration.

(3) Northern-Atlantic Ocean: an ultra-deep hemipelagic mudstone was collected from the New-Foundland margin, at ODP site 1276, in September 2003 during the ODP Leg 210 mission (R/V Joides Resolution), as described elsewhere (Roussel et al., 2008, SOM). Contamination tests following the ODP standard procedure for microbiological samples (particulate tracers) indicated that this sample was suitable for microbiological investigations (Roussel et al., 2008, SOM). It is noteworthy that the sediment fraction stored at $-20^{\circ} \mathrm{C}$ was used for other molecular studies (Roussel et al., 2008); therefore, we worked with duplicate fractions stored at $4^{\circ} \mathrm{C}$. Our present results, in addition to the cultivation of indigenous subsurface microorganisms from these crude samples (data not shown) confirmed that the microbial communities from this sample were well-preserved.

\subsection{Microbial strains and addition to sterilized sediment}

Thermococcus siculi strain RG-20 ${ }^{\top}$ (Grote et al., 1999), Marinitoga piezophila strain KA3 ${ }^{\top}$ (Alain et al., 2002) and Caldiclava thermospodii strain OLG2 ${ }^{\top}$ (new genus of Firmicutes, Le Romancer et al. unpublished) were used as seed organisms for the positive controls. These representatives of Archaea, Gram-negative Bacteria and sporulating Gram-positive Bacteria, respectively, were grown to late exponential phase before being mixed, in the proportions 1:1:1, with sterilized sediment (silt) from which amplifiable DNA could not be obtained. The cell suspensions were added to DNA-free sediment to a final concentration of $\sim 1.0 \times 10^{6}$ cells per cubic centimetre sediment. 


\subsection{Physical disruption with a cryogenic mill and cell counts}

Mechanical lysis of $\sim 1 \mathrm{~g}$ thawed sediments was performed in a cryogenic laboratory mill (6770 Freezer/Mill, Spex SamplePrep, NJ, USA). Nine Freezer/Mill programs consisting of different durations and different beating rates were tested on clay, silt and sandy sediments from the Mediterranean Sea. These programs were as follows: a pre-cooling time for 2 min, pulverization time (at a given beating rate) for $1 \mathrm{~min}$ and post-pulverization cooling time for 3 min. Tested programs were composed of one or two cycles at one beating rate of either 6,8 , $10,12,14$ or 15 units ( 1 unit corresponds to 2 impacts per second).

The efficiency of cell disruption was monitored by microscopic cell counts (Olympus BX60 microscope, WIB filter) using the SYBR Green I staining procedure. When counting could not be performed immediately after cryogenic mill disruption, $10 \mu \mathrm{l}$ of samples were fixed with $2 \%(\mathrm{v} / \mathrm{v})$ formaldehyde in $10 \mathrm{ml} \mathrm{NaCl} 3 \%(\mathrm{w} / \mathrm{v})$ solution. Fixed samples were then filtered through polycarbonate membrane filters (pore size: $0.22 \mu \mathrm{m}$ ), washed and air-dried. Filters were then placed on microscope slides, stained with $50 \mu \mathrm{l}$ SYBR Green I 10x (Molecular Probes-Invitrogen, Carlsbad, CA, USA) and mounted with $100 \mu \mathrm{l}$ of an anti-fading solution $(0.1 \%(\mathrm{w} / \mathrm{v}) \mathrm{N}-\mathrm{Ndimethyl}-1,4-$ phenylene diamine sulphate, $0.42 \%(\mathrm{w} / \mathrm{v}) \mathrm{NaCl}, 0.44 \%$ (w/v) $\mathrm{Na}_{2} \mathrm{HPO}_{4}, 0.495 \%(\mathrm{v} / \mathrm{v})$ glycerol) modified from Patel et al. (2007). Cell counts were obtained using a BX60 fluorescence microscope (Olympus) on $0.2 \mu \mathrm{m}$ filters (Isopore ${ }^{\mathrm{TM}}$ GTTP membrane filters, Millipore).

For each sediment type, four Freezer/Mill programs were selected for further DNA extraction treatments. These treatments included; (i) two most effective Freezer/Mill programs in terms of cell disruption efficiency; and (ii) two mild programs to control the DNA shearing, given that the subsequent extraction procedures include additional lysis steps.

\subsection{DNA extraction}

A total of fifteen DNA extraction procedures were evaluated and compared on a silt sample from the Tasman Sea. Each sediment sample was divided into $\sim 1 \mathrm{~g}$ (wet weight) subsamples (and also the positive control). DNA was extracted from duplicate subsamples for each of the fifteen different methods. Nucleic acids extracted from each duplicate sample (from $1 \mathrm{~g}$ sediment fraction) were suspended in $10 \mu \mathrm{l}$ to $200 \mu \mathrm{l} \mathrm{TE}-1 \mathrm{X}$ buffer (10 mM Tris$\mathrm{HCl}, 2$ mM EDTA, pH 7.5).

In thirteen procedures, a freezer/mill apparatus was used to crush samples and disrupt cells (mechanical lysis in a liquid nitrogen chamber). These procedures are derived from four main methods (see Table 2):

- Fz-P Method: Freezer/Mill lysis followed by phenol/chloroform DNA extraction. This method was evaluated at beating rates 8, 14 and 15. After crushing in a cryogenic mill, extracts were suspended in $1 \mathrm{ml}$ TE-Na-1X lysis buffer (100 $\mathrm{mM}$ Tris, $50 \mathrm{mM}$ EDTA, $100 \mathrm{mM} \mathrm{NaCl}, \mathrm{pH} \mathrm{8.0)}$ and extracted with equal volumes of buffered phenol/chloroform/isoamylic alcohol (PCl: 25/24/1; $\mathrm{pH}$ 8.0). Following recovery of the aqueous phase, a second extraction with $\mathrm{PCl}$ was performed. In the second round, the extraction was performed with equal volumes of chloroform. Solutions were subjected to centrifugation at $13000 \mathrm{~g}$ for $15 \mathrm{~min} .\left(4^{\circ} \mathrm{C}\right)$, aqueous phases were recovered and then supplemented with $200 \mu \mathrm{g}$ linear acrylamide (Ambion/Applied Biosystems) to favour precipitation of nucleic acid (linear acrylamide does not interfere with $A_{260 / 280}$ readings). DNA was precipitated overnight at $-20^{\circ} \mathrm{C}$ with 0.7 volumes of icecold isopropanol. The precipitate was pelleted by centrifugation at maximum 
speed for $10 \mathrm{~min}$, air-dried and dissolved in TE-1X buffer to a final volume of $50 \mu \mathrm{l}$.

- Fz-chem1-P Method: Freezer/Mill lysis followed by chemo-enzymatic treatment (detergents + proteolytic enzyme) and then by phenol/chloroform extraction. This method was evaluated at beating rates $5,8,14$ and 15 . Sample homogenization in cryogenic mill, suspension in TE-1X buffer, centrifugation and supernatant collection were as described in method Fz-P. These were followed by successive additions of $100 \mu \mathrm{l}$ Sarkosyl $(10 \% \mathrm{w} / \mathrm{v})$, $100 \mu \mathrm{l} \mathrm{SDS} \mathrm{(10 \%} \mathrm{w/v)} \mathrm{and} 20 \mu \mathrm{l}$ proteinase $\mathrm{K}\left(20 \mathrm{mg} \mathrm{ml}^{-1}\right.$; Eurobio). After gentle inversion by hand, these preparations were incubated for $1 \mathrm{~h}$ at $55^{\circ} \mathrm{C}$, and centrifuged for $20 \mathrm{~min}$. at $8000 \mathrm{~g}\left(4^{\circ} \mathrm{C}\right)$ to pellet cell debris. Final steps were similar to those described in method Fz-P. Briefly they included two extractions with $\mathrm{PCl}$, extraction with chloroform and nucleic acid precipitation.

- Fz-chem2-P Method: Freezer/Mill lysis followed by chemical treatment (detergent + chaotropic agent) and then by phenol/chloroform extraction. This method was performed at beating rates 14 and 15 . The procedure was similar to method Fz-chem1-P with the exception that the chemo-enzymatic treatment was replaced by a treatment with detergent and chaotropic agent. Briefly, the first steps were as in method Fz-chem1-P: homogenization in cryogenic mill, suspension in TE-1X buffer and centrifugation, and then, supernatants were treated with $150 \mu \mathrm{l}$ sarkosyl (10\%) and $1 \mathrm{ml}$ GTC (guanidine thiocyanate $4 \mathrm{M}$ ). Samples were incubated at $20^{\circ} \mathrm{C}$ for $30 \mathrm{~s}$ and centrifuged at $8000 \mathrm{~g}$ for $20 \mathrm{~min}\left(4^{\circ} \mathrm{C}\right)$. Nucleic acids were extracted with $\mathrm{PCl}$ as described previously.

- Fz-Mag Method: Freezer/Mill lysis followed by nucleic acid absorption to magnetic silica beads. Sediments were crushed in a Freezer/Mill apparatus at beating rates 8,14 and 15 . Preparations were then suspended in $0.5 \mathrm{ml}$ TE$\mathrm{Na}-1 \mathrm{X}$ lysis buffer and centrifuged for $20 \mathrm{~min}$ at $8000 \mathrm{rpm}\left(4^{\circ} \mathrm{C}\right)$ to pellet debris. Supernatants were then extracted using the commercial kit 'MagExtractor-PCR \& Gel Clean Up' (CosmoBio Co., Tokyo, Japan) following the manufacturer's instructions. Briefly, DNA was directly recovered by absorption to magnetized silica beads in the presence of chaotropic agents, washed and eluted.

Two of the most commonly used protocols for DNA extraction from sediments were also tested:

- F Method: Commercial kit FastDNA ${ }^{\circledR}$ SPIN kit for Soil (Qbiogene, MP Biomedicals, Illkirch, France) with modifications as essentially described in Webster et al. (2003). Briefly, this method is based on a mechanical homogenization of samples with ceramic and silica beads, in a Bead Beater cell disruptor (FastPrep® Instrument, MP Biomedicals, Illkirch, France), and in the presence of chaotropic DNA stabilizing agents (proprietary mixture of detergents and salts). Following cell lysis, DNA was bound to a silica matrix, washed and then eluted. $200 \mu \mathrm{g}$ linear acrylamide were further added to the sediment/lysis buffer mix prior to cell lysis. With this kit, DNA can be extracted from sediment samples weighing less than $0.5 \mathrm{~g}$. As a consequence, total DNA was extracted from four consecutive $0.5 \mathrm{~g}$ subsamples in order to standardize and compare results to those obtained from the other protocols (duplicate extractions on $1 \mathrm{~g}$ subsamples). 
- Z Method: Zhou method (Zhou et al., 1996). Briefly, sediments were freezethawed in a high-salt extraction buffer containing CTAB and $1.5 \mathrm{M} \mathrm{NaCl}$. Samples were then treated with proteinase $\mathrm{K}$ and SDS, and extracted with chloroform-isoamyl alcohol.

These different protocols were used on the sediments collected from the Tasman Sea, and were then applied on all other samples in order to compare the efficacy of these methods to different sediments and depths.

\subsection{DNA concentration and quality}

DNA quantity was routinely determined using an ultra-sensitive fluorescent nucleic acid stain: the Quant-it ${ }^{\mathrm{TM}}$ PicoGreen ${ }^{\circledR}$ dsDNA kit (Invitrogen). Concentrations of DNA were normalized to sediment dry weight after desiccation $\left(70^{\circ} \mathrm{C}, 30 \mathrm{~h}\right)$. DNA purity was evaluated by determining the ratios of $A_{260} / A_{280}$ and $A_{260} / A_{230}(\mathrm{~nm})$ by a NanoDrop $\AA$ ND-1000 spectrophotometer (Thermo Fisher Scientific).

In order to determine the DNA fragment size, crude extracts $(5 \mu \mathrm{l})$ were subjected to electrophoresis in 1X TAE buffer ( $\mathrm{pH} 8,40 \mathrm{mM}$ Tris base, $20 \mathrm{mM}$ acetic acid, $1 \mathrm{mM}$ EDTA) in a $0.75 \%(\mathrm{w} / \mathrm{v})$ agarose gel at $85 \mathrm{~V}$, stained with $0.5 \mu \mathrm{g} / \mathrm{ml}$ ethidium bromide and visualized under ultraviolet trans-illumination. Lambda DNA Hindll-digest (Sigma) was used as marker for size determination.

\subsection{Ribotype diversity shown by PCR-DGGE}

DNA extracts from the Tasman Sea, North Atlantic Ocean (protocols Fz-8, Fz-chem1-P-8, Fz-chem2-P-8, Fz-Mag-8 and F), and from positive controls were all subjected to $16 \mathrm{~S}$ rRNA gene PCR-Denaturing Gel gradient Electrophoresis (DGGE) analysis to characterize the bacterial and archaeal diversity. Using PCR-DGGE, it is possible to rapidly obtain banding patterns of the dominant microbial populations, and to sequence these bands. PCR-DGGE analysis was performed on pooled fractions of DNA extracts obtained from duplicate extractions. Nested PCR was performed in all cases to optimize the DGGE results. Bacterial 16S rRNA gene amplification was conducted with primers Bac8F (5'-AGA GTT TGA TCC TGG CTC AG-3') and Bac1493R (5'-GTT ACC TTG TTA CGA CTT-3') for the first round, and with 341F-GC (5'-CGC CCG CCG CGC CCC GCG CCC GTC CCG CCG CCC CCG CCC GCC TAC GGG AGG CAG CAG-3') and 907R (5'-CCG TCA ATT CMT TTG AGT TT3') for the second round. PCR cycles for the first round (Bac8F/Bac1493R) were: a denaturation step of $1 \mathrm{~min}$ at $94^{\circ} \mathrm{C}, 30$ cycles consisting of $1 \mathrm{~min}$ at $94^{\circ} \mathrm{C}, 1.5 \mathrm{~min}$ at $50^{\circ} \mathrm{C}$ and $2 \mathrm{~min}$ at $72^{\circ} \mathrm{C}$; and a final step of $6 \mathrm{~min}$ at $72^{\circ} \mathrm{C}$. PCR cycles for the second round (341F-GC/907R) were: a denaturation step of $3 \mathrm{~min}$ at $94^{\circ} \mathrm{C}, 20$ cycles consisting of $1 \mathrm{~min}$ at $94^{\circ} \mathrm{C}, 1 \mathrm{~min}$ at $55^{\circ} \mathrm{C}$ and $1.5 \mathrm{~min}$ at $72^{\circ} \mathrm{C}$; and a final step of $7 \mathrm{~min}$ at $72^{\circ} \mathrm{C}$. Archaeal $16 \mathrm{~S}$ rRNA gene amplification was conducted with primers Arc21F (5'-TTC CGG TTG ATC CTG CCG GA-3') and Arc958R (5'-YCC GGC GTT GAM TCC AAT T-3') for the first round, and with Arc344F-GC (5'-CGC CCG CCG CGC CCC GCG CCC CCG CCG CCC GAC GGG GYG CAG CAG GCG CGA-3') and Arc915R (5'-GTG CTC CCC CGC CAA TTC CT-3') for the second round. PCR cycles for the first round (Arc21F/Arc958R) were as follows: a denaturation step of $5 \mathrm{~min}$ at $94^{\circ} \mathrm{C}, 30$ cycles consisting of $1 \mathrm{~min}$ at $94^{\circ} \mathrm{C}, 1.5 \mathrm{~min}$ at $54^{\circ} \mathrm{C}$ and $2 \mathrm{~min}$ at $72^{\circ} \mathrm{C}$; and a final step of $6 \mathrm{~min}$ at $72^{\circ} \mathrm{C}$. PCR cycles for the second round (Arc344F-GC/Arc915R) were: a first step of $3 \mathrm{~min}$ at $94^{\circ} \mathrm{C}, 20$ cycles consisting of $1 \mathrm{~min}$ at $94^{\circ} \mathrm{C}, 1 \mathrm{~min}$. at $57^{\circ} \mathrm{C}$ and $1.5 \mathrm{~min}$ at $72^{\circ} \mathrm{C}$; and a final step of $7 \mathrm{~min}$ at $72^{\circ} \mathrm{C}$. DGGE was performed with the Bio-Rad DCode Universal Mutation Detection System on a $1 \mathrm{~mm}$ thick $(16 \times 16 \mathrm{~cm}) 6 \%$ (w/v) polyacrylamide gel (acrylamide/bisacrylamide, 37.5/1, BioRad), with 
denaturant at a $20 \%$ to $80 \%$ gradient prepared as described elsewhere (Roussel et al., 2009). Electrophoresis was run for $10 \mathrm{~min}$ at $80 \mathrm{~V}$ and then for $330 \mathrm{~min}$ at $200 \mathrm{~V}$, in $1 \mathrm{X}$ TAE buffer at $60^{\circ} \mathrm{C}$. The gel was stained with $S Y B R^{\circledR}$ Gold nucleic acid gel stain (Molecular Probes, Invitrogen) for $45 \mathrm{~min}$ and visualised using an UV transilluminator. The strongest DGGE bands were excised, reamplified by PCR and sequenced by Sanger method (Cogenics Beckman-Coulter, Stansted, U.K.). Sequences were compared to sequences from the databases using NCBI BLASTN (http://www.ncbi.nlm.nih.gov). They were then aligned using CLUSTALX and classified into taxonomic units by phylogenetic reconstruction, using neighbour-joining (with Jukes and Cantor correction) in PHYLIP 3.69.

\section{Results}

\subsection{Impact of different cryogenic mill programs on cell lysis efficiency}

Lysis efficiency was deduced from averaged microscopic cell counts performed before and after cryogenic mill treatment. Nine different cryogenic mill programs, at different durations ( 1 or 2 cycles) and beating rates, were evaluated on three sediment types: clay, silt and fine sand (all from the Mediterranean Sea) (Table 3). As expected, higher percentages of lysed cells were obtained from sandy sediments as compared to muddy sediments. Lysis efficiency improved with increased beating rates, regardless of the sediment texture. With sandy sediments, lysis efficiency ranged from $64 \%$, at beating rate 6 , to $96 \%$, at beating rate 15 (maximal power). With clay, these values ranged from $43 \%$, at beating rate 8 , to $62 \%$, at beating rate 15 . The repetition of a full cycle of cryogenic mill after the first cycle did not increase lysis efficiencies.

\subsection{Quantity and purity of nucleic acids extracted by different procedures}

Nanodrop and Quant-it yielded different results. The former one overestimated the DNA yields. Consequently, only the Quant-it measurements were taken into account.

Large variations in DNA yields were obtained with the different extraction procedures and with the different measurement methods (Table 4). The DNA yields obtained with the Tasman Sea sample, ranged from 13 to $1073 \mathrm{ng} / \mathrm{g}$ dry weight of sediment. In our tested protocols, the lowest DNA yields were obtained using the Zhou protocol, while the highest yields were obtained using a Freezer/Mill cycle at beating rate 8 followed by phenol/chloroform extraction (method Fz-P-8). Excepted with the Mediterranean Sea sample from $3.03 \mathrm{mbsf}$, the diverse Freezer-Mill-based approaches gave higher DNA yields than the classical bead-beating (FastDNA ${ }^{\circledR}$ SPIN kit) and freeze-thawing (Zhou protocol) methods. Among the Freezer-mill-based procedures, those based on direct use of $\mathrm{PCl}$ (method Fz-P) or use of SDS/sarkosyl/proteinase $\mathrm{K}$ and $\mathrm{PCl}$ (method Fz-chem1-P), resulted in the highest DNA yields. For a given procedure, the beating rate 8 consistently generated the highest yields. Concentration of DNA decreased with increasing beating rates suggesting that DNA was sheared and damaged at higher beating rates (i.e. beating rates 14 or 15).

$A_{260} / A_{230}$ and $A_{260} / A_{280}$ absorbance ratios for the DNA extracted by Fz-P, Fz-chem1-P and Fz-chem2-P were generally above 1.8, indicating that the DNA extracts resulting from these protocols were relatively pure and contained low amounts of humic acids, proteins or other contaminants. On the other hand, the absorbance ratios for DNA extracted by Fz-Mag, $F$ and $Z$ methods were not within the range of 1.8-1.9. However, this discrepancy is explained by the presence of substances absorbing at 230 or $280 \mathrm{~nm}$ in commercial kits or solutions used in these procedures. Further, DNA fragment size from crude extracts could not be estimated from ethidium bromide stained gels (data not shown), nor from highly 
concentrated DNA extracts. Similar detection problems are reported in the literature showing comparable DNA yields (Miller et al., 1999; Aguilera et al., 2006). Except for the extraction of DNA using the $Z$ method, amplification of bacterial and archaeal sequences encoding for 16S rRNA genes was successfully obtained by nested-PCR for all other protocols. The signal was relatively weak or absent after the first PCR, but robust for almost all samples after nested PCR amplification. Intensely stained bands at the expected size were observed at the end of the second round of PCR for all samples, with the exception of the clay-rich sediments that resulted in weakly stained bands (data not shown). Accordingly, further purifications steps were not necessary.

\subsection{Taxonomic diversity as shown by PCR-DGGE}

To compare the microbial diversity recovered via the different methods, molecular fingerprinting was performed using PCR-DGGE-sequencing on community DNA extracted from sediments with methods Fz-P-8, Fz-chem1-P-8, Fz-Mag-8 and F. In our study, we targeted variable regions ( $\sim 50-610$ bp in size) of bacterial and archaeal 165 rRNA genes. Interestingly, whatever the sediment and whatever the targeted domain (Bacteria or Archaea), we consistently observed the following: (i) method Fz-P-8 gave the highest number of bands on the DGGE pattern, (ii) DGGE patterns showing the highest diversity (as determined by the largest number of bands), were classed as follows: Fz-P-8 $>\mathrm{F} \approx \mathrm{Fz}-\mathrm{Mag}$ 8 > Fz-chem1-P-8; (iii) the diversity shown by PCR-DGGE-sequencing was high but not similar in crude extracts obtained by Fz-P-8, Fz-Mag-8, and F methods; and (iv) positive controls gave the expected results (detection of the 3 seed microorganisms: Thermococcus siculi, Marinitoga piezophila, Caldiclava thermospodii) with methods Fz-P-8, Fz-chem1-P-8, Fz-Mag-8 and F (Figure 1 and data not shown).

The subsurface sediments from the Tasman Sea, the Northern Atlantic Ocean and the Mediterranean Sea displayed complex PCR-DGGE banding patterns, with 5 to 21 bands (Figure 1 and data not shown). A large fraction of the taxonomic groups, detected by sequencing of the DGGE bands, belonged to uncultured lineages frequently retrieved from marine subsurface sediments, such as the Miscellaneous Crenarcheotic Group (MCG), the Deep-Sea Archaeal Group (DSAG)(synonymous with the MBG-B: Marine Benthic Group B) or the South African Gold Mine Group (SAGMEG) (Figure 1). When regarding the phyla and the candidate divisions that were detected by PCR-DGGE-sequencing, all were detected from DNA extracts Fz-P-8 and F, but some were absent from extracts Fz-chem1-P-8 and FzMag-8. At the phylotype-level, the microbial diversity shown by methods Fz-P-8 and F was slightly different, suggesting that it could be interesting to combine both methods to obtain larger diversity estimates.

\subsection{Comparison of DNA extraction procedures based on DNA yield, purity and taxonomic diversity as shown by PCR-DGGE}

Among the different procedures tested, the Freezer-Mill-based approaches gave the highest yields. The methods resulting in high DNA quality, in terms of $A_{260} / A_{230}$ and $A_{260} / A_{280}$ ratios, were the Freezer-Mill-based methods Fz-P, Fz-chem1-P and Fz-chem2-P, respectively. For tested sediments, most methods (except for the $Z$ method) provided good quality DNA for downstream PCR analysis. Finally, DNA extraction procedures showing the largest diversity by PCR-DGGE-sequencing were methods Fz-P-8 and F.

Based on these results we can conclude that use of the Fz-P-8 method results in highquality and -quantity DNA, and at the same time offers great recovery of prokaryotic diversity. 
In order to validate this method and evaluate its cell lysis efficiency on sediments from various depths (3.03 to 1626 mbsf), different physical-chemical properties (Table 1) and diverse cell densities (from $1.6 \times 10^{6}$ to $2.1 \times 10^{8} \mathrm{cells} / \mathrm{cm}^{3}$ ), crude DNA was extracted from five natural sediments using the Fz-P-8 approach (Table 5). Cell lysis efficiency was evaluated by cell counting (before and after mechanical disruption in the cryogenic mill), and by microscopic observations of the various phases and interphase collected after the first $\mathrm{PCl}$ extraction. Indeed, phenol efficiently denatures proteins and $\mathrm{PCl}$ extraction acts to lyse the remaining intact cells. Whatever the nature of the sediment and its microbial abundance (with the exception of sediments containing large amounts of clay), we observed very few cells after the $\mathrm{PCl}$ extraction. This suggests that most cells were lysed using this method. Crude DNA extracts of high-quality for downstream PCR analyses were obtained from all five sediments tested, including the one with the lowest cellular abundance. The DNA yield obtained with the positive control was close to the theoretical value, calculated on the basis of cell abundance (Table 5). Crude DNA yields obtained from natural sediments were at one exception in the expected values and rather high (Table 5). The value from the North Atlantic Ocean sample was greatly higher than the expected DNA yield, but this can be explained by the presence of eukaryotic DNA in this sample (Alain et al., unpublished results). Interestingly, DNA extraction efficiency was comparable for samples containing low- and high-cell numbers (when microbial abundances were between $1.1 \times 10^{6}$ and $2.1 \times 10^{8}$ cells $\left./ \mathrm{cm}^{3}\right)$.

\section{Discussion}

Obtaining DNA from deep subsurface sediments is a difficult task because cell abundance generally decreases with depth, in the presence of complex organic matter, and enzymatic inhibitors are omnipresent. In addition, harsh environmental conditions that characterize the subsurface habitat, notably the high pressures, the high temperatures at depth and low energy fluxes, favour the settlement of microorganisms that are resistant to classical lysis. Examples of these include microorganisms with membrane compositions reducing energy loss and hard to degrade cell-wall compositions (tetra-ether based membranes such as in Archaea; glycolipids; etc) (Valentine, 2007), as well as biofilms or resting cells (ie. spores, cysts).

The aim of this work was to devise the basic protocol for a cryogenic-mill-based DNA extraction procedure suitable to recovering high yields of DNA and identifying diversity from deep marine sediments. Among the tested protocols, the Fz-P-8 method offered the highest DNA yields and recovery of diversity. This method derived from traditional procedures is based on a cryogenic mill disruption at beating rate 8 followed by two extractions with $\mathrm{PCl}$ and one with chloroform. More drastic cryogenic-mill-based methods or conditions, based on higher beating rates or on additional lysis treatments (chemical, osmotic or enzymatic treatments), led to a loss of diversity and/or to shearing DNA. While DNA extraction from clay-rich samples was less effective, cell lysis efficiencies and DNA extracting efficiencies were generally higher and better with method Fz-P-8 than with other methods tested here or reported in the literature (Wang and Edwards, 2009). This procedure gave much higher DNA yields than the Zhou protocol and FastDNA ${ }^{\circledR}$ SPIN kit for soils, the two methods most commonly used. Moreover, for all the investigated sediments FZ-P-8 provided crude DNA extracts that were directly used for nested PCR amplification without requiring additional purification. Nevertheless, we observed that the amplification efficiency decreased after two months (data not shown), suggesting that our protocol could be improved. Future studies to investigate the effect of DNA stabilization reagents on the storage of DNA, the effect of nucleic acid carriers or other polyvalent polymers on the adsorption and degradation of DNA [e.g. skim milk powder, Denhardt's solution; and contaminants discussed herein (Volossiouk et al., 1995; Wang and Edwards, 2009)], are necessitated. 
In summary, the DNA extraction method Fz-P-8 described herein is simple, rapid and costeffective. It provides high efficiency for cell lysis and DNA yield for most sediment types (except for clay-rich samples) and for a myriad of experimental goals. In addition, this method can be used directly without a further purification step for most PCR-mediated assays of subsurface communities, including diversity studies and pyrosequencing. In combination with nested-PCR (known to provide much higher levels of sensitivity), DNA extracted with this method was successfully used to describe the composition of ultra-deep subsurface sediments from cell numbers as low as $1.1 \times 10^{6} \mathrm{cells} / \mathrm{cm}^{3}$. This method may be advantageous to other methods described to-date, as it can be adapted to various sediment types and to different experimentations. More importantly, it can be easily implemented in microbiology laboratories. Nevertheless, taking into consideration the remarkable complexity of sediment types and the different parameters that may interfere with DNA extractions, this protocol should be considered as a basic configuration that can be amended for a wider scope of analyses. Certain sediment types or purposes will likely require specific modifications or further purification of their target DNA. While one method for DNA extraction from all sediment types is unlikely, herein we provide the footing for a ubiquitous protocol that can be easily amended for all experimental goals.

\section{Acknowledgements}

The authors are sincerely indebted to Patrice Woerther, Bernard Dennielou and Serge Berné, the chief scientists of the oceanographic cruises ESSCAR-9 and RHOSOS. The Tasman Sea sample was collected by Geoscience Australia in the Australian maritime jurisdiction during the AUSFAIR survey and results presented here are with permission from Geoscience Australia. This work was supported by the Centre National de la Recherche

Scientifique and the Universite de Bretagne Occidentale. M.-C.C. was supported by a grant from the Ministère de la Recherche and a Transfer of Knowledge grant from the CAREX network.

\section{References}

Aguilera, A., Gómez, F., Lospitao, E., Amils, R., 2006. A molecular approach to the characterization of the eukaryotic communities of an extreme acidic environment: methods for DNA extraction and denaturing gradient gel electrophresis. System. Appl. Microbiol. 29, 593-605.

Alain, K., Marteinsson, V.T., Miroshnichenko, M., Bonch-Osmolovskaya, E., Prieur, D., Birrien, J.L., 2002. Marinitoga piezophila, sp. nov., a rod-shaped thermopiezophilic bacterium isolated under high hydrostatic pressure from a deep-sea hydrothermal vent. Int. J. Syst. Evol. Microbiol. 52, 1331-1339.

Bakken, L.R., Olsen, R.A., 1989. DNA content of soil bacteria of different cell size. Soil Biol. Biochem. 21, 789-793.

Courtois, S., Frostegård, A., Göransson, P., Depret, G., Jeannin, P., Simonet, P., 2001. Quantification of bacterial subgroups in soil : comparison of DNA extracted directly from soil or from cells previously released by density gradient centrifugation. Environ. Microbiol. 3, 431-439.

Fry, J.C., Parkes, R.J., Cragg, B.A., Weightman, A. J., Webster, G., 2008. Prokaryotic biodiversity and activity in the deep subseafloor biosphere. FEMS Microbiol. Ecol. 66, 181-196.

Grote, R., Li, L., Tamaoka, J., Kato, C., Horikoshi, K., Antranikian, G., 1999. Thermococcus siculi sp. nov., a novel hyperthermophilic archaeon isolated from a deep-sea hydrothermal vent at the Mid-Okinawa Trough. Extremophiles. 3, 55-62. 
Leff, L.G., Dana, J.R., McArthur, J.V., Shimkets, L.J., 1995. Comparison of methods of DNA extraction from stream sediments. Appl. Environ. Microbiol. 61, 1141-1143.

Lipp, J. S., Morono, Y., Inagaki, F., Hinrichs, K.U., 2008. Significant contribution of Archaea to extant biomass in marine subsurface sediments. Nature. 454, 991-994.

Luna, G.M., Dell'Anno, A., Danovaro, R., 2006. DNA extraction procedure: a critical issue for bacterial diversity assessment in marine sediments. Environ. Microbiol. 8, 308-320.

Madsen E.L., 1996. A critical analysis of methods for determining the composition and biogeochemical activities of soil microbial communities in situ. Soil Biochem. 9, 287-370.

Martin-Laurent, F., Philippot, L., Hallet, S., Chaussod, R., Germon, J.C., Soulas, G., Catroux, G., 2001. DNA extraction from Soils: Old bias for new microbial diversity analysis methods. Appl. Environ. Microbiol. 67, 2354-2359.

Massie, H.R., Zimm, B.H., 1965. Molecular weight of the DNA in the chromosomes of E.coli and B.subtilis. Proc Natl Acad Sci USA. 54, 1636-1641.

Miller, D. N., Bryant, J. E., Madsen, E. L., Ghiorse, W.C., 1999. Evaluation and optimization of DNA extraction and purification procedures for soil and sediment samples. Appl. Environ. Microbiol. 65, 4715-4724.

Patel, A., Noble, R.T., Steele, J.A., Schwalbach, M.S., Hewson, I., Fuhrman, J.A, 2007. Virus and prokaryote enumeration from planktonic aquatic environments by epifluorescence microscopy with SYBR Green I. Nature Protocols. 2, 269-276.

Roussel, E.G., Cambon-Bonavita, M.-A., Querellou, J., Cragg, B.A., Webster, G., Prieur, D., Parkes, R.J., 2008. Extending the Sub-Sea-Floor Biosphere. Science. 320, 1046.

Roussel, E.G., Sauvadet, A.-L., Allard, J., Chaduteau, C., Richard, P., CambonBonavita, M.-A., Chaumillon, E., 2009. Archaeal methane cycling communities associated with gassy subsurface sediments of Marennes-Oléron Bay (France). Geomicrobiol. J. 26, 31-43.

Schippers, A., Neretin, L. N., Kallmeyer, J., Ferdelman, T.G., Cragg, B.A., Parkes, R.J., Jørgensen, B.B., 2005. Prokaryotic cells of the deep sub-seafloor biosphere identified as living bacteria. Nature. 433, 861-864.

Steffan, R.J., Goksøyr, J., Bej, A. K., Atlas, R.M., 1988. Recovery of DNA from soils and sediments. Appl. Environ. Microbiol. 54, 2908-2915.

Valentine, D.L., 2007. Adaptations to energy stress dictate the ecology and evolution of the Archaea. Nature Rev. Microbiol. 5, 316-323.

Volossiouk, T., Robb, E.J., Nazar, R.N., 1995. Direct DNA extraction for PCRmediated assays of soil organisms. Appl. Environ. Microbiol. 61, 3972-3976.

Wang, H., Edwards, K.J., 2009. Bacterial and archaeal DNA extracted from inoculated experiments: Implication for the optimization of DNA extraction from deepsea basalts. Geomicrobiol. J. 26, 463-469.

Webster, G., Newberry, C.J., Fry, J.C., Weightman, A.J., 2003. Assessment of bacterial community structure in the deep sub-seafloor biosphere by 165 rDNAbased techniques: a cautionary tale. J. Microbiol. Methods. 55, 155-164.

Zhou, J., Bruns, M.A., Tiedje, J.M., 1996. DNA recovery from soils of diverse composition. Appl. Environ. Microbiol. 62, 316-322. 
Table 1 Location and properties of the subsurface sediments used in cell disruption tests and DNA extraction methods

\begin{tabular}{|c|c|c|c|c|c|}
\hline & \multicolumn{5}{|l|}{ Sediment } \\
\hline Location & $\begin{array}{c}\text { Mediterranean } \\
\text { Sea } \\
\end{array}$ & $\begin{array}{c}\text { Mediterranean } \\
\text { Sea } \\
\end{array}$ & \begin{tabular}{|c|} 
Mediterranean \\
Sea
\end{tabular} & Tasman Sea & $\begin{array}{c}\text { Northern } \\
\text { Atlantic Ocean }\end{array}$ \\
\hline $\begin{array}{l}\text { Sampling } \\
\text { location }\end{array}$ & $\begin{array}{c}\text { Var } \\
\text { sedimentary } \\
\text { Ridge } \\
\left(43^{\circ} 23 \mid 016 \mathrm{~N},\right. \\
\left.07^{\circ} 44 \mathbf{l}^{\prime} 187 \mathrm{E}\right) \\
\end{array}$ & $\begin{array}{l}\text { Gulf of Lions } \\
\left(42^{\circ} 411^{\prime} \mid 596 \mathrm{~N},\right. \\
\left.03^{\circ} 500^{\prime} 493 \mathrm{E}\right)\end{array}$ & $\begin{array}{c}\text { Var } \\
\text { sedimentary } \\
\text { Ridge } \\
\left(43^{\circ} 23^{\prime} \mid 16 \mathrm{~N},\right. \\
\left.07^{\circ} 44 \text { I }^{\prime} 187 \mathrm{E}\right) \\
\end{array}$ & $\begin{array}{l}\left(27^{\circ} 466^{\prime 6} 5 \mathrm{~S},\right. \\
\left.160^{\circ} 10154 \mathrm{E}\right)\end{array}$ & $\begin{array}{c}\text { New- } \\
\text { Foundland } \\
\text { margin } \\
\left(45^{\circ} 24 \mid 3198 \mathrm{~N},\right. \\
\left.44^{\circ} 47 \mathbf{I}^{\prime} 1496 \mathrm{~W}\right)\end{array}$ \\
\hline Depth (mbsf) & 3.03 & 5.40 & 6.84 & 21 & 1626 \\
\hline $\begin{array}{l}\text { Water depth } \\
\text { (m) }\end{array}$ & 2160 & 291 & 2160 & 2546 & 4560 \\
\hline $\begin{array}{l}\text { Sediment } \\
\text { texture }\end{array}$ & silt & clay & fine sand & silt & mudstone \\
\hline $\begin{array}{l}\text { In situ } \\
\text { temperature } \\
\left({ }^{\circ} \mathrm{C}\right)\end{array}$ & $10-12$ & $10-12$ & $12-13$ & $2.5-4$ & $60-100^{b}$ \\
\hline Salinity (ă ) & 37.9 & 37.9 & 40.1 & 27.3 & ND \\
\hline TOC (\%) & 0.30 & 0.39 & 0.05 & ND & 0.87 \\
\hline TC (\%) & 4.45 & 4.95 & 3.87 & ND & ND \\
\hline $\begin{array}{l}\text { Period } \\
\text { (geologic } \\
\text { time), age } \\
\text { (years) }\end{array}$ & $\begin{array}{l}\text { Holocene, } \\
\text { Age }<10 \text { ky }\end{array}$ & $\begin{array}{c}\text { Late } \\
\text { Pleistocene, } \\
\text { 18.7-18.8 ky }\end{array}$ & $\begin{array}{l}\text { Holocene, } \\
\text { Age }<10 \text { ky }\end{array}$ & $\begin{array}{c}\text { Early } \\
\text { Pleistocene, } \\
\text { between } 0.78 \\
\text { and } 2.59 \mathrm{My}\end{array}$ & $\begin{array}{c}\text { Cretaceous, } \\
111 \mathrm{My}\end{array}$ \\
\hline Used & $\begin{array}{l}\text { To compare } \\
\text { various } \\
\text { cryogenic mill } \\
\text { lysis programs } \\
\text { (different } \\
\text { durations, } \\
\text { various } \\
\text { beating rates) }\end{array}$ & $\begin{array}{l}\text { To compare } \\
\text { various } \\
\text { cryogenic mill } \\
\text { lysis programs } \\
\text { (different } \\
\text { durations, } \\
\text { various } \\
\text { beating rates) }\end{array}$ & $\begin{array}{l}\text { To compare } \\
\text { various } \\
\text { cryogenic mill } \\
\text { lysis programs } \\
\text { (different } \\
\text { durations, } \\
\text { various } \\
\text { beating rates) }\end{array}$ & $\begin{array}{l}\text { - To validate } \\
\text { the } \\
\text { freezer/mill } \\
\text { programs } \\
\text { giving the best } \\
\text { cell disruption } \\
\text { efficiencies } \\
\text { - To compare } \\
\text { different DNA } \\
\text { extraction } \\
\text { procedures }\end{array}$ & $\begin{array}{l}\text { To validate the } \\
\text { most efficient } \\
\text { DNA } \\
\text { extraction } \\
\text { procedures }\end{array}$ \\
\hline
\end{tabular}

Abbreviations: ND, not determined; TOC, total organic carbon; TC, total carbon.

a Textures are defined as follow: - fine sand: dominance of particles with size $<125 \mu \mathrm{m}$

- silt: dominance of particles with size $<62.5 \mu \mathrm{m}$

- clay: dominance of particles with size $<3.9 \mu \mathrm{m}$

${ }^{\mathrm{b}}$ Estimation of the in situ temperature (Roussel et al., 2008) 
Table 2 Summary of the DNA extraction procedures performed on Tasman Sea samples

\begin{tabular}{|c|c|c|c|c|c|}
\hline \multirow[t]{2}{*}{ Method } & \multicolumn{5}{|c|}{ Cell lysis treatment and nucleic acid extraction procedure } \\
\hline & $\begin{array}{l}\text { Mechanical for } \\
\text { Freezer/Mill }\end{array}$ & $\begin{array}{l}\text { Beating } \\
\text { rate }^{\mathrm{a}}\end{array}$ & Chemical/osmotic & Enzymatic & Binding matrix \\
\hline $\begin{array}{l}\text { Fz-P-8 } \\
\text { Fz-P-14 } \\
\text { Fz-P-15 }\end{array}$ & $\begin{array}{l}\text { Freezer/Mill } \\
\text { Freezer/Mill } \\
\text { Freezer/Mill }\end{array}$ & $\begin{array}{l}8 \\
14 \\
15\end{array}$ & $\begin{array}{l}\mathrm{PCl} \\
\mathrm{PCl} \\
\mathrm{PCl}\end{array}$ & & \\
\hline Fz-chem1-P-5 & Freezer/Mill & 5 & & $\begin{array}{l}\text { Proteinase } \\
\mathrm{K}\end{array}$ & \\
\hline Fz-chem1-P-8 & Freezer/Mill & 8 & SDS, Sarkosyl / PCI & $\begin{array}{l}\text { Proteinase } \\
\mathrm{K}\end{array}$ & \\
\hline Fz-chem1-P-14 & Freezer/Mill & 14 & SDS, Sarkosyl / PCI & $\begin{array}{l}\text { Proteinase } \\
\mathrm{K}\end{array}$ & \\
\hline Fz-chem1-P-15 & Freezer/Mill & 15 & SDS, Sarkosyl / PCI & $\begin{array}{l}\text { Proteinase } \\
\mathrm{K}\end{array}$ & \\
\hline $\begin{array}{l}\text { Fz-chem2-P-14 } \\
\text { Fz-chem2-P-15 }\end{array}$ & $\begin{array}{l}\text { Freezer/Mill } \\
\text { Freezer/Mill }\end{array}$ & $\begin{array}{l}14 \\
15\end{array}$ & $\begin{array}{l}\text { Sarkosyl, GCT / PCI } \\
\text { Sarkosyl, GCT / PCI }\end{array}$ & & \\
\hline Fz-Mag-5 & Freezer/Mill & 5 & & & $\begin{array}{l}\text { Magnetic silica } \\
\text { beads } \\
\left.\text { (MagExtractor }{ }^{\circledR}\right)\end{array}$ \\
\hline Fz-Mag-8 & Freezer/Mill & 8 & & & $\begin{array}{l}\text { Magnetic silica } \\
\text { beads } \\
\left.\text { (MagExtractor }{ }^{\circledR}\right)\end{array}$ \\
\hline Fz-Mag-14 & Freezer/Mill & 14 & & & $\begin{array}{l}\text { Magnetic silica } \\
\text { beads } \\
\left.\text { (MagExtractor }{ }^{\circledR}\right)\end{array}$ \\
\hline Fz-Mag-15 & Freezer/Mill & 15 & & & $\begin{array}{l}\text { Magnetic silica } \\
\text { beads } \\
\text { (MagExtractor }{ }^{\circledR} \text { ) }\end{array}$ \\
\hline $\mathrm{F}$ & $\begin{array}{l}\text { Bead Beating } \\
\text { (FastDNA® } \\
\text { SPIN kit for } \\
\text { Soil) }\end{array}$ & & & & Silica beads \\
\hline Z & $\begin{array}{l}\text { Freeze- } \\
\text { thawing } \\
\text { (Zhou } \\
\text { protocol) }\end{array}$ & & $\begin{array}{l}\text { Saline buffer, SDS, } \\
\text { CTAB / Cl }\end{array}$ & $\begin{array}{l}\text { Proteinase } \\
\mathrm{K}\end{array}$ & \\
\hline
\end{tabular}

a 1 unit of beating rate corresponds to 2 impacts per second

Abbreviations: $\mathrm{PCl}$ or $\mathrm{Cl}$ (Phenol)/Chloroform/Isoamylic alcohol; SDS, Sodium Dodecyl Sulphate; GCT, Guanidine Thiocyanate; CTAB, hexadecylTrimethylAmmonium Bromide 
Table 3 Percentages of lysed cells after physical disruption with a cryogenic mill. Results are shown as a function of the sediment nature and of the Freezer/Mill program

\begin{tabular}{|c|c|c|c|c|c|c|c|c|c|}
\hline & \multicolumn{9}{|c|}{$\%$ lysis efficiency ${ }^{a}$} \\
\hline $\begin{array}{c}\text { Beating rate } \\
\text { units }^{b} \times \text { cycle } \\
\text { number }\end{array}$ & $5 \times 1$ & $6 \times 1$ & $8 \times 1$ & $10 \times 1$ & $12 \times 1$ & $14 \times 1$ & $15 \times 1$ & $14 \times 2$ & $15 \times 2$ \\
\hline Fine sand $^{\mathrm{C}}$ & NT & $64 \pm 8$ & $86 \pm 5$ & $87 \pm 2$ & $91 \pm 2$ & $95 \pm 1$ & $96 \pm 2$ & NT & NT \\
\hline Silt $^{d}$ & $48 \pm 4$ & $55 \pm 7$ & $81 \pm 2$ & $81 \pm 1$ & $82 \pm 3$ & $85 \pm 1$ & $87 \pm 1$ & NT & NT \\
\hline Clay $^{e}$ & NT & NT & $43 \pm 5$ & $51 \pm 5$ & $51 \pm 8$ & $52 \pm 9$ & $62 \pm 3$ & $56 \pm 9$ & $65 \pm 5$ \\
\hline
\end{tabular}

Abbreviation: NT, not tested

${ }^{a}$ for each condition, percentages were calculated from mean counts (with $n=3$ ) performed before and after treatment with the cryogenic mill; cells were enumerated by direct microscopic counts of samples stained with SYBR Green I.

${ }^{\mathrm{b}} 1$ unit of beating rate corresponds to 2 impacts per second

${ }^{c}$ Dominance of particles with size $<125 \mu \mathrm{m}$

${ }^{\mathrm{d}}$ Dominance of particles with size $<62.5 \mu \mathrm{m}$

${ }^{\mathrm{e}}$ Dominance of particles with size $<3.9 \mu \mathrm{m}$ 
Table 4 Comparison of DNA yields and purities for crude DNA from deep subseafloor sediments subjected to different treatments

\begin{tabular}{|c|c|c|c|c|c|}
\hline Sample & \multicolumn{2}{|c|}{ Method } & $\begin{array}{l}\text { DNA yield ( } \mathrm{ng} / \mathrm{g} \\
\text { dry weight of } \\
\text { sediment) }\end{array}$ & $\begin{array}{c}\text { Ratio } \\
A_{260} / A_{230} \mathrm{~b}\end{array}$ & $\begin{array}{c}\text { Ratio } \\
A_{260} / A_{280}\end{array}$ \\
\hline \multirow{15}{*}{$\begin{array}{l}\text { Tasman Sea } \\
21 \text { mbsf }\end{array}$} & \multirow{3}{*}{ Freezer/Mill + PCl } & Fz-P-8 & $1073 \pm 248$ & $2.10 \pm 0$ & $2.15 \pm 0.08$ \\
\hline & & Fz-P-14 & $504 \pm 28$ & $1.99 \pm 0.08$ & $1.93 \pm 0.25$ \\
\hline & & Fz-P-15 & $376 \pm 35$ & $1.88 \pm 0.11$ & $1.78 \pm 0.03$ \\
\hline & \multirow{4}{*}{$\begin{array}{c}\text { Freezer/Mill + SDS, } \\
\text { sarkosyl, } \\
\text { proteinase K / PCl }\end{array}$} & Fz-chem1-P-5 & $588 \pm 32$ & $2.39 \pm 0.24$ & $1.99 \pm 0.03$ \\
\hline & & Fz-chem1-P-8 & $672 \pm 161$ & $1.98 \pm 0.25$ & $1.90 \pm 0.35$ \\
\hline & & Fz-chem1-P-14 & $424 \pm 22$ & $1.91 \pm 0.04$ & $1.92 \pm 0.06$ \\
\hline & & Fz-chem1-P-15 & $497 \pm 199$ & $1.46 \pm 0.15$ & $1.70 \pm 0.18$ \\
\hline & \multirow{2}{*}{$\begin{array}{c}\text { Freezer/Mill + GCT, } \\
\text { sarkosyl / PCl }\end{array}$} & Fz-chem2-P-14 & $252 \pm 13$ & $2.0 \pm 2.23$ & $2.04 \pm 0.21$ \\
\hline & & Fz-chem2-P-15 & $126 \pm 14$ & OR & $1.75 \pm 0.01$ \\
\hline & \multirow{4}{*}{$\begin{array}{l}\text { Freezer/Mill + } \\
\text { Magnetic silica } \\
\text { beads }\end{array}$} & Fz-Mag-5 & BDL & OR & OR \\
\hline & & Fz-Mag-8 & $74 \pm 9$ & OR & OR \\
\hline & & Fz-Mag-14 & $60 \pm 39$ & OR & OR \\
\hline & & Fz-Mag-15 & $16 \pm 4$ & OR & $2.08 \pm 0.35$ \\
\hline & $\begin{array}{c}\text { Bead Beating } \\
\text { (FastDNA }{ }^{\circledR} \text { SPIN for } \\
\text { soil kit) }\end{array}$ & $\mathrm{F}$ & $49 \pm 3$ & OR & 1.94 \\
\hline & $\begin{array}{l}\text { Freeze-thawing } \\
\text { (Zhou protocol) }\end{array}$ & Z & $13 \pm 3$ & $1.26 \pm 0.57$ & $1.25 \pm 0.08$ \\
\hline \multirow{9}{*}{$\begin{array}{c}\text { Northern Atlantic } \\
\text { Ocean }\end{array}$} & \multirow{2}{*}{ Freezer/Mill + PCl } & Fz-P-8 & $695 \pm 123$ & $1.72 \pm 0.32$ & $1.73 \pm 0.24$ \\
\hline & & Fz-P-14 & $91 \pm 10$ & $1.84 \pm 0$ & $1.78 \pm 0.06$ \\
\hline & \multirow{3}{*}{$\begin{array}{c}\text { Freezer/Mill + SDS, } \\
\text { sarkosyl, } \\
\text { proteinase K / PCI }\end{array}$} & Fz-chem1-P-5 & $318 \pm 186$ & $2.13 \pm 0.08$ & $1.82 \pm 0$ \\
\hline & & Fz-chem1-P-8 & $696 \pm 124$ & $1.75 \pm 0.32$ & $1.73 \pm 0.24$ \\
\hline & & Fz-chem1-P -14 & $679 \pm 120$ & $1.54 \pm 0.14$ & $1.83 \pm 0.01$ \\
\hline & \multirow{3}{*}{$\begin{array}{l}\text { Freezer/Mill + } \\
\text { Magnetic silica } \\
\text { beads }\end{array}$} & Fz-Mag-5 & 5 & OR & OR \\
\hline & & Fz-Mag-8 & $58 \pm 5$ & OR & OR \\
\hline & & Fz-Mag-14 & $35 \pm 1$ & OR & $1.91 \pm 0.01$ \\
\hline & $\begin{array}{c}\text { Bead Beating } \\
\text { (FastDNA }{ }^{\circledR} \text { SPIN for } \\
\text { soil kit) }\end{array}$ & $\mathrm{F}$ & $72 \pm 1$ & OR & 1.94 \\
\hline \multirow[b]{2}{*}{$\begin{array}{l}\text { Mediterranean Sea } \\
3.03 \text { mbsf (silt) }\end{array}$} & Freezer/Mill + PCl & Fz-P-8 & 548 & 0.57 & 1.58 \\
\hline & $\begin{array}{c}\text { Bead Beating } \\
\text { (FastDNA }^{\circledR} \text { SPIN for } \\
\text { soil kit) }\end{array}$ & $\mathrm{F}$ & 2941 & OR & 1.58 \\
\hline \multirow[t]{2}{*}{$\begin{array}{c}\text { Mediterranean Sea } \\
5.40 \text { mbsf (clay) }\end{array}$} & Freezer/Mill + PCl & Fz-P-8 & 2192 & 1.93 & 1.77 \\
\hline & $\begin{array}{c}\text { Bead Beating } \\
\text { (FastDNA }{ }^{\circledR} \text { SPIN for }\end{array}$ & $\mathrm{F}$ & 1626 & OR & 2.09 \\
\hline
\end{tabular}




\begin{tabular}{|c|c|c|c|c|c|}
\hline & soil kit) & & & & \\
\hline \multirow{15}{*}{$\begin{array}{l}\text { Mediterranean Sea } \\
6.84 \text { mbsf (sand) }\end{array}$} & Freezer/Mill + PCl & Fz-P-8 & 3520 & 1.33 & 1.80 \\
\hline & $\begin{array}{c}\text { Bead Beating } \\
\text { (FastDNA }{ }^{\oplus} \text { SPIN for } \\
\text { soil kit) }\end{array}$ & $\mathrm{F}$ & 1736 & OR & 1.90 \\
\hline & \multirow{3}{*}{ Freezer/Mill + PCl } & Fz-P-8 & $11 \pm 2$ & $1.98 \pm 0.20$ & $1.93 \pm 0.35$ \\
\hline & & Fz-P-14 & $8 \pm 1$ & $1.98 \pm 0.08$ & $1.92 \pm 0.05$ \\
\hline & & Fz-P-15 & $2 \pm 1$ & $1.89 \pm 0.40$ & $1.73 \pm 0.11$ \\
\hline & \multirow{4}{*}{$\begin{array}{c}\text { Freezer/Mill + SDS, } \\
\text { sarkosyl, } \\
\text { proteinase K / PCI }\end{array}$} & Fz-chem1-P-5 & $8 \pm 1$ & $2.21 \pm 0.15$ & $1.99 \pm 0.06$ \\
\hline & & Fz-chem1-P-8 & $11 \pm 2$ & $1.93 \pm 0.31$ & $2.01 \pm 0.23$ \\
\hline & & Fz-chem1-P-14 & $8 \pm 1$ & $1.94 \pm 0.06$ & $1.98 \pm 0.01$ \\
\hline & & Fz-chem1-P-15 & $7 \pm 1$ & $1.92 \pm 0.17$ & $1.92 \pm 0.37$ \\
\hline & \multirow{2}{*}{$\begin{array}{c}\text { Freezer/Mill + GCT, } \\
\text { sarkosyl / PCl }\end{array}$} & Fz-chem2-P-14 & $5 \pm 1$ & $2.03 \pm 0.28$ & $1.99 \pm 0.06$ \\
\hline & & Fz-chem2-P-15 & $3 \pm 1$ & $1.77 \pm 0.26$ & $1.85 \pm 0.02$ \\
\hline & \multirow{4}{*}{$\begin{array}{l}\text { Freezer/Mill + } \\
\text { Magnetic silica } \\
\text { beads }\end{array}$} & Fz-Mag-5 & $2 \pm 1$ & $1.26 \pm 0.01$ & OR \\
\hline & & Fz-Mag-8 & $3 \pm 0$ & $1.56 \pm 0.12$ & OR \\
\hline & & Fz-Mag-14 & $1 \pm 0$ & OR & OR \\
\hline & & Fz-Mag-15 & $1 \pm 0$ & OR & OR \\
\hline
\end{tabular}

Legend:

DNA yield $>1000 \mathrm{ng} / \mathrm{g}$ dry weight of sediment

DNA yield $>500 \mathrm{ng} / \mathrm{g}$ dry weight of sediment

DNA yield $>200 \mathrm{ng} / \mathrm{g}$ dry weight of sediment

DNA yield $>50 \mathrm{ng} / \mathrm{g}$ dry weight of sediment

DNA yield $<50 \mathrm{ng} / \mathrm{g}$ dry weight of sediment

Ratio $>1.80$

$1.80>$ ratio $>1.50$

Ratio $<1.50$

${ }^{a}$ Values are means, \pm standard errors, with $\mathrm{n}=2$

${ }^{b}$ Nucleic acids absorb light that has a wavelength of $260 \mathrm{~nm}$. Organic contaminants like phenol and other aromatic compounds, humic acids, TRIzol and reagents commonly used in DNA extraction kits absorb at $230 \mathrm{~nm}$ wavelength. The maximal absorption of proteins is at $280 \mathrm{~nm}$. $\mathrm{A}_{260} / \mathrm{A}_{230}$ ratios $\mathrm{B} 1.9$, and $A_{260} / 280$ ratios in the range of $B 1.8$ to $œ 2.0$, are generally recommended for any molecular analysis.

OR: out-of-range value: very low or very high absorbance value due to the presence of contaminants. BDL: below the detection limit. 
Table 5: Direct counts and DNA yields using the DNA extraction procedure Fz-P-8

\begin{tabular}{|l|c|c|c|c|}
\hline Sample & $\begin{array}{c}\text { Microbial } \\
\text { abundance } \\
\text { (cells per }_{\mathbf{c m}^{\mathbf{3}} \mathbf{a}}^{\mathbf{a}}\end{array}$ & $\begin{array}{c}\text { \% lysis efficiency } \\
\text { after Freezer/Mill } \\
\text { treatment (beating } \\
\text { rate 8) }\end{array}$ & $\begin{array}{c}\text { Expected DNA } \\
\text { yield (ng/g [wet } \\
\text { wt] of sediment) }\end{array}$ & $\begin{array}{c}\text { Crude DNA yield } \\
\text { (ng/g [wet wt] of } \\
\text { sediment) }\end{array}$ \\
\hline $\begin{array}{l}\text { Mediterranean } \\
\text { Sea 3.03 mbsf } \\
\text { (silt) }\end{array}$ & $2.1 \times 10^{8}$ & 81 & $336-(1450)-2790$ & 454 \\
\hline $\begin{array}{l}\text { Mediterranean } \\
\text { Sea 5.40 mbsf } \\
\text { (clay) }\end{array}$ & $1.5 \times 10^{8}$ & 43 & $240-(1040)-2000$ & 1871 \\
\hline $\begin{array}{l}\text { Mediterranean } \\
\text { Sea 6.84 mbsf } \\
\text { (fine sand) }\end{array}$ & $1.5 \times 10^{8}$ & 86 & $240-(1040)-2000$ & 2816 \\
\hline $\begin{array}{l}\text { Tasman Sea 21 } \\
\text { mbsf }\end{array}$ & $7.5 \times 10^{7}$ & 82 & $120-(518)-998$ & 954 \\
\hline $\begin{array}{l}\text { North. Atlantic } \\
\text { Ocean } 1626 \\
\text { mbsf }\end{array}$ & $1.6 \times 10^{6}$ & 88 & $2.56-(11)-21.3$ & 640 \\
\hline Positive control & $1.1 \times 10^{6}$ & 94 & $1.76-(7.59)-14.6$ & \\
\hline
\end{tabular}

${ }^{\mathrm{a}}$ Microscopic counts of SYBR ${ }^{\circledR}$ Green I-stained cells

${ }^{b}$ Range of expected DNA yields calculated by multiplying the number of prokaryotic cells by low, middle (under brackets) and high values previously reported in the literature for cellular DNA content of environmental bacteria [mean cellular DNA content of soil bacteria $\left(1.6 \times 10^{\text {c15 }} \mathrm{g}\right.$ cell $\left.{ }^{\text {C1 }}\right)$ as reported by Bakken and Olsen (1989), cellular DNA content of Escherichia coli strain B $\left(6.9 \times 10^{\text {cis }} \mathrm{g}\right.$ cell ${ }^{\text {C1 }}$ for a genome of $4.67 \mathrm{Mb}$ ) as calculated by Massie and Zimm (1965), and estimated cellular content of a $9 \mathrm{Mb}$ genome such as those encountered among Actinobacteria and Bacillus/Clostridium ( $1.33 \times 10^{\text {cl14 }}$ $\mathrm{g}$ cell $\left.^{\text {fi }}\right)$ ]. NB: These calculations are based on the hypothesis that the community is exclusively composed of prokaryotes.

${ }^{\mathrm{C}}$ Encysted forms of eukaryotes were detected in this sample (data not shown). 


\section{Figures}

Figure 1 Schematic diagram of the DGGE results obtained with the Tasman Sea sample and the North Atlantic Ocean sample, using the different DNA extraction procedures. The strongest DGGE bands were excised and sequenced. Bar texture shows their taxonomic affiliation. Legend: DSAG, Deep-Sea Archaeal Group; MCG, Miscellaneous Crenarcheotic Group; SAGMEG, South African Gold Mine Group; Not determined, weak DGGE bands which have not been sequenced.

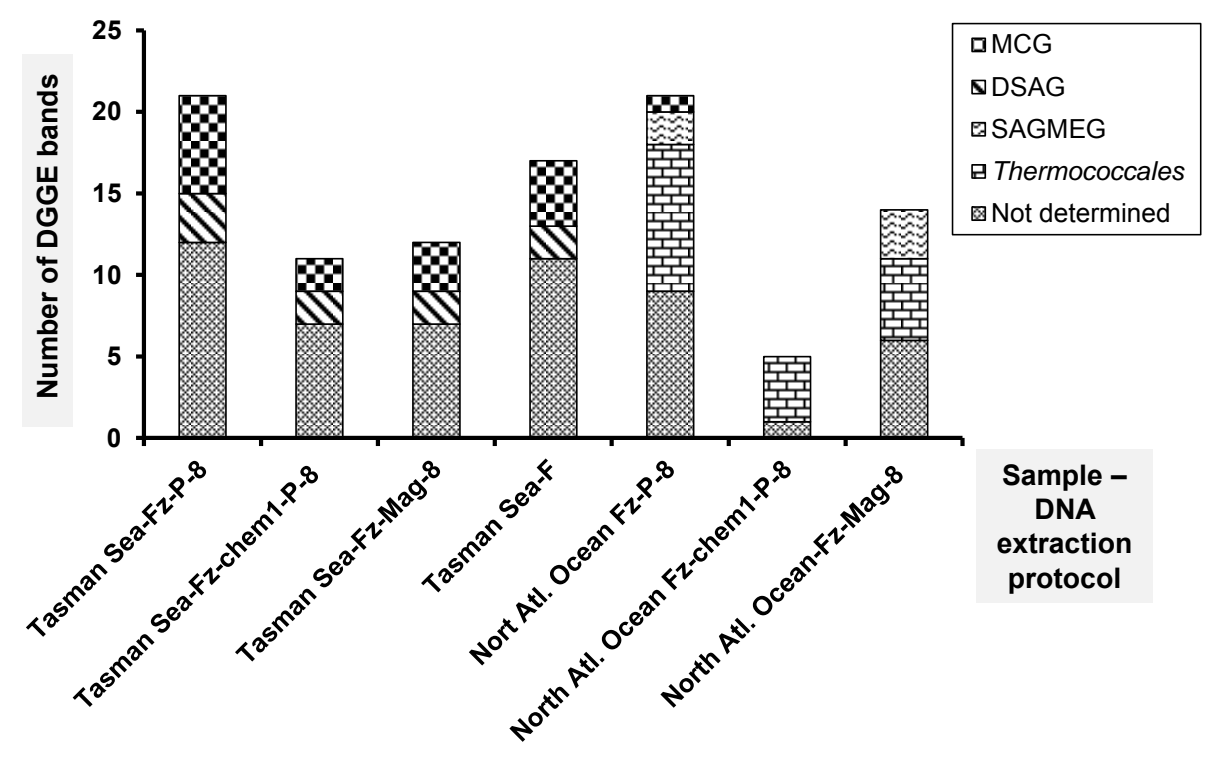

